\title{
Studies on Bone Marrow Cells in Experimental Animals : Bone Marrow Testing in the Safety Study
}

\author{
Kiyoshi MATSUMOTO \\ Institute of Experimental Animals, Shinshu University School of Medicine, \\ 3-1-1 Asahi, Matsumoto-shi, Nagano 390, Japan
}

I. Introduction

\section{Contents}

II. Application of bone marrow testing to the safety study

1) Preface

2) Methods of bone marrow examination

3) Normal bone marrow cell composition throughout the life of rats and mice

4) Effects on bone marrow following administration of specific drugs and/or feed restriction

III. Bone marrow in immune-deficient animals and immunotoxicity testing

N. Further problems

\section{I . Introduction}

The bone marrow represents a widely dispersed organ system comprised of a heterogenous population of cells, and multipotential stem cells in bone marrow cavity are directly or indirectly responsible for all blood cell formation.

Total volume of bone marrow cavities is estimated to be $4.5 \%$ of body weight in man [16] as well as in experimental animals (2.5$3 \%$ ) $[12,32]$, which is comparable to the liver in size.

In normal adult rats, the bone marrow's daily production and export of blood cells amounts to about $5 \times 10^{9}$ red cells, $4 \times 10^{10}$ platelets, and $3 \times 10^{8}$ leukocytes per body. This rate of production is adjusted to actual needs.

On the other hand, the safety study, where the toxicity of chemicals such as drugs, food color additives, pesticides, medical devices for human use and biological products are evaluated by animal experiments, is very important to insure the protection of human health and the environment. Following exposure to the chemicals under investigation, a number of organs and tissues are carefully examined for possible toxic effects in the animal models. In the Japanese toxicology testing guidelines, however, bone marrow examination consisting of total nucleated and differential cell counts is not now required [29, 37].

However, many new drugs and/or biological products (e. g. hormons, cytokines, blood products) [35] resulting from recent developments in recombinant and hybridoma technologies may specifically affect the immune system including blood and bone marrow. In case of cytokines, attention to possible toxic effects on the bone marrow as a target organ is, therefore, becoming increasingly important.

Thus, in this paper some of our recent data concerning the normal bone marrow cell count and its composition, application of bone marrow testing to toxicity studies and effects of feed restriction on bone marrow cells including methods of bone marrow examination are presented, and the importance and necessity of hematological bone marrow examination in the safety study are discussed. 


\section{II . Application of bone marrow testing to the safety study}

\section{Preface}

In the safety study, extensive hematologic, chemical, and histopathological evaluations are required for preclinical assessment of drug toxicity. In terms of the myelo-and/or hematotoxicological evaluation, bone marrow should be examined hematologically, and enumeration of the formed elements of both peripheral blood and bone marrow are necessary. Nevertheless, in many laboratories examination of bone marrow is still histopathologically performed on slides fixed with $10 \%$ neutral formalin and stained with hematoxylin-eosin (H-E) for toxicological evaluation. Because an unavoidable atrophy (about 30\%) of cells and tissue occurs in routine preparations as mentioned above, histopathological evaluation is flawed both in a numeric sense as well as in its ability to detect morphological fine feature of cells for differentiation of maturation stage.

For the purpose of application of bone marrow testing to the safety study, fundamental experiments concerning bone marrow cells of experimental animals as belowmentioned were performed.

2. Methods of bone marrow examination

1) Sampling of bone marrow

Bone marrow for toxicological examination may be obtained by aspiration through a needle or directly removed at autopsy.

The site chosen for sampling marrow depends on the animal species and/or test systems. In the study of rats and mice, the femur is selected because this bone containes sufficient volume to measure the total nucleated and differential cell counts. In dogs as well as monkeys, marrow is easily obtainable through the sternum ( $3 \mathrm{rd}$ to 5 th interspaces) using a Komiya pediatric needle under light anesthesia by ketamine injection.

2) Nucleated bone marrow cell counts and cellularity of normal experimental animals

In order to obtain useful quantitative data, cells in diluted bone marrow cell suspension as mentioned below are enumerated by manual methods or by an automated cell counting method. There are two ways of expressing

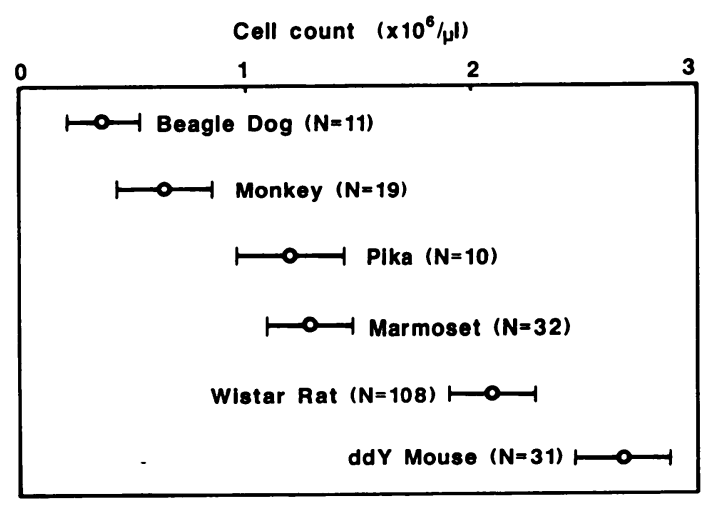

Fig. 1. Femoral bone marrow cell counts of experimental animals

Bone marrows of dogs (9-12 months old), monkeys (2-3 years old), pika (10-15 months old), marmosets (1-2 years old), rats (10-15 weeks old) and mice (9-15 weeks old) were removed at autopsy, and total number of nucleated : cells were measured using Coulter Counter, model D (Coulter Electronics Inc.). Each value represents the mean $\pm \mathrm{SD}$.

total nucleated bone marrow cell counts : (1) as number of cells per a femur, by the method of flushing out the bone marrow with fetal bovin serum, and (2) as number of cells per $1 \mu \mathrm{l}$ of bone marrow, which is directly obtained using forceps at autopsy and accurately diluted using blood diluting pipette.

Fig. 1 shows my own experimental results of the number of nucleated cells per $1 \mu \mathrm{l}$ of femoral bone marrow of several species of experimental animals. The mean values of bone marrow cellularity are $2.67 \times 10^{6}$ in the mouse, $2.12 \times 10^{8}$ in the rat, $1.28 \times 10^{6}$ in the marmoset, $1.20 \times 10^{6}$ in the pika, $0.64 \times 10^{6}$ in the monkey and $0.35 \times 10^{\circ}$ in the dog, respectively, indicating an inverse relationship between body size and cellularity.

3) Preparation of bone marrow film

Many microscopic, biochemical, and histochemical methods have been proposed to identify the various types of mature and immature bone marrow cells, but relatively simple morphologic procedures remain the standard for toxicological purposes. Morphology has its limitations but carefully prepared and stained blood and marrow films provide information that is indispensable for safety evaluation of chemicals.

In the case of marrow aspiration in dogs 
Table 1. Morphological characteristics of bone marrow cells in experimental animals

\begin{tabular}{ll}
\hline Mouse & $\begin{array}{l}\text { Ring form nucleus (immature granulocyte, monocyte), } \\
\text { Twisted coil form nucleus (mature neutrophil and } \\
\text { eosinophil) }\end{array}$ \\
$\begin{array}{l}\text { Rat } \\
\text { Rabbit }\end{array}$ & $\begin{array}{l}\text { Intensely red cytoplasm (neutrophil) } \\
\text { Dog }\end{array}$ \\
Monkey & $\begin{array}{l}\text { Diffusely pink or colorless cytoplasm (neutrophil) } \\
\text { Hypersegmentation (neutrophil), } \\
\text { Marmoset }\end{array}$ \\
\hline
\end{tabular}

and monkeys, marrow film is made by the wedge method or by using a spinner (a centrifuge that provides rapid rotation of the slide in a horizonal plane). At autopsy, an automatic cell smearing instrument, Cytospin [2, 11], is recommended for use in preparing smears for rodents, dogs, and monkeys. The reason is as follows: Morphological criteria to be considered in differentiating bone marrow cells include cell size, primary and secondary (specific) granules in cytoplasm of granulocytes, nuclear shape, color of cytoplasm etc. suggesting that the information from cytoplasm is important to identify the cell. In this respect, this cytospin method has an advantage in that the most information can be easily and consistently obtained from cytoplasm, over other methods. The morphological characteristics of bone marrow cells on the marrow film by this cytospin preparation in experimental animals are represented (Table 1).

There is an issue to be addressed in differential bone marrow cell counting. Because a large number of cell types are normally present and their distribution is irregular, it is necessary to identify and tabulate a large number of cells. As imprecision in counting is directly related to the number of cells evaluated, the fewer cells that are assessed, the greater the likelihood and degree imprecision. Thousand nucleated cells, from my experience, is necessary to obtain a significant differential count and estimate the granulocytes/erythroids ratio (G/E ratio), both useful parameters in evaluating the state of bone marrow. However, it is important to remember that the differential bone marrow cell count is very imprecise when based upon the examination of a relatively small number of cells, i. e., blasts, basophils, reticulum cells.

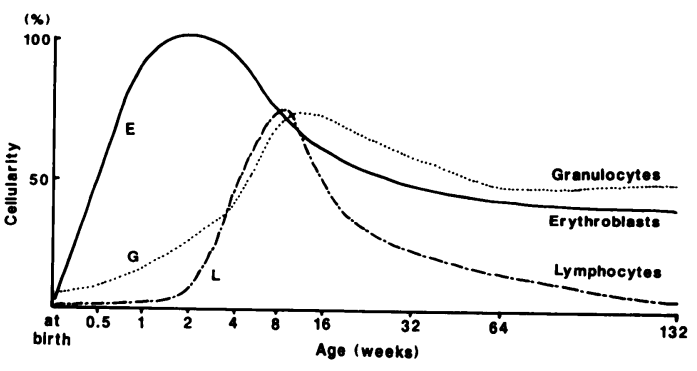

Fig. 2. Hematopoiesis of femoral bone marrow in rat

On the basis of the data on cellularity of erythroblasts, granulocytes and lymphocytes, age-associated changes of these cell types are shown when the maximum value of erythroblasts at 2 weeks of age is normalized to $100 \%$.

Additionally, the differential bone marrow cell count, in general, is expressed both in percentage and absolute number of each cell type per $1 \mu$ l of bone marrow or per a femur. As each data set is usually evaluated statistically in the safety study, it is preferably expressed in absolute numbers rather than in percentages.

3 . Normal bone marrow cell composition throughout the life of rats and mice

When introducing a new test system of bone marrow examination into a safety study, it is important to establish normal ranges for the parameters to be examined. At first, changes of bone marrow cell composition of rats, generally used in safety study, from 0 (at birth) to 2.5 years old $[23,27]$ and that of mice [21] from 0 to 2 years old were studied and summarized data of rats are shown in Fig. 2 .

The numbers of bone marrow cells in rat at birth are quite low but during the first 
several weeks of postnatal life gradual increases in erythroblasts, granulocy tes and lymphocytes, in order, are seen. It is noteworthy that the $\mathrm{G} / \mathrm{E}$ ratio is 7.3 at birth (day 0 ) and 0.2 on day four, and since the G/E ratio of adult rat is normally from 0.6 to 2.7 [36] or from 0.8 to 1.8 (my historical data), these values would be the highest and lowest respectively for the whole life span of a rat. These findings in rats during the first several weeks were similar to those in mice (data not shown). These results suggested that for the first 8 weeks of life, there is a precarious balance between the need for blood cells of a rapidly growing infant and the available bone marrow space, and reactivation of hepatic and splenic hematopoiesis takes place whenever there is an increased demand for blood cell formation.

The G/E ratio increased by 9 weeks of age and became a constant value thereafter (1.1), indicating this was the rat's maturational age using marrow cells as an indicator, and it was comparable with the sexual maturation time of male rat [44].

After 9 weeks of age, the number of lymphocytes gradually and continuously decreased, suggesting the decline of immune response with age. In man it has also found that above age 65 the total leukocyte count tends to be lower, due primarily to a decrease in the lymphocyte count $[5,9]$.

4. Effects on bone marrow following administration of specific drugs and/or feed restriction

1) Effect of mitomycin $\mathrm{C}$ on bone marrow cells
For a trial, time-course effects on bone marrow cell and peripheral reticulocyte counts after a single ip injection of $2 \mathrm{mg} / \mathrm{kg}$ mitomycin $\mathrm{C}$ to mice were studied [22]. The total numbers of both bone marrow cells and reticulocytes were reduced after injection, and the lowest values of bone marrow cell count $(45 \%$ of control) and reticulocyte count (5\% of control) were found at day 2 and day 4 , respectively. Many reports [7, 13, 18, 34, 40], including this one, suggest that the changes of bone marrow cell composition would be observed within four days following administration of anticancer drugs or chemicals with direct effect on bone marrow cells.

Of interest, but still inadequately explained, is the finding that the percentage of lymphocytes is usually elevated when the bone marrow cell count is low. This and other findings $[24,28]$ suggest that the percentage of lymphocytes may be useful as an index of bone marrow cellularity (Table 2).

2) Effect of four days drug administration on bone marrow cells

To develop a short-term test system to detect drug-induced myelotoxicity, hematological examinations of the bone marrow and peripheral blood in rats following repeated four-day administration of phenylhydrazine (PHZ), 5-fluorouracil (5-FU), or p-sec-butylphenol (BP) were performed (Fig. 3) [27]. Following chemical exposure, there was an increase in the number of erythroblasts due to anemia by PHZ treatment, a decrease in erythroblasts without marked changes in the number of peripheral blood cells by BP

Table 2. Effect of mitomycin $\mathrm{C}$ on bone marrow differential cell count in mice

\begin{tabular}{lrrrrr}
\hline \multirow{2}{*}{ Differential (\%) } & \multicolumn{5}{c}{ days after injection } \\
\cline { 2 - 6 } & \multicolumn{1}{c}{0} & \multicolumn{1}{c}{ 4hrs } & \multicolumn{1}{c}{1} & \multicolumn{1}{c}{2} & \multicolumn{1}{c}{4} \\
\hline Pro- and basophilic Ebls ${ }^{1)}$ & 3.8 & 3.2 & 1.9 & 3.8 & 5.0 \\
Polychromatic Ebls & 27.5 & 23.3 & 10.8 & 7.2 & 15.2 \\
$\quad$ Total Ebls & 31.3 & 26.5 & 12.7 & 11.0 & 20.2 \\
Immature $^{2)}$ Granulo. & 6.0 & 6.6 & 7.8 & 5.5 & 14.1 \\
Mature $^{3)}$ Granulo. & 45.8 & 50.5 & 62.6 & 54.5 & 35.6 \\
$\quad$ Total Granulo. & 51.8 & 57.1 & 70.4 & 60.0 & 49.7 \\
Lymphocytes & 15.2 & 14.0 & 14.5 & 26.2 & 26.5 \\
Other cells & 1.7 & 2.4 & 2.4 & 2.8 & 3.6 \\
\hline
\end{tabular}

Values are means of 7 animals.

1) Ebl: Erythroblasts, 2) Immature : Promyelocytes and myelocytes,

3) Mature : Metamyelocytes, stab and segmented forms. 


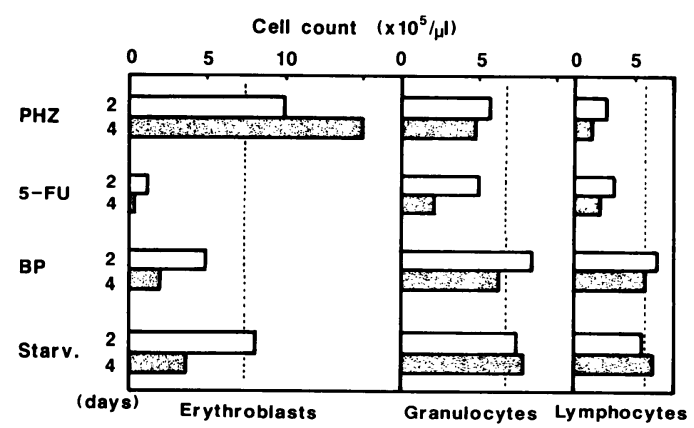

Fig. 3. Effect of 4 days drug administration on femoral bone marrow cells in rats

Phenylhydrazine(PHZ;8.3mg/kg/day, s.c.), 5-fluolouracil (5-FU; 45mg/kg/day, s. c.) or p-sec-butylphenol (BP ; 800mg/kg/day, p.o.) was administered to male Slc : Wistar rats for four days. Each bar represents the mean of five animals. Dotted line shows control value.

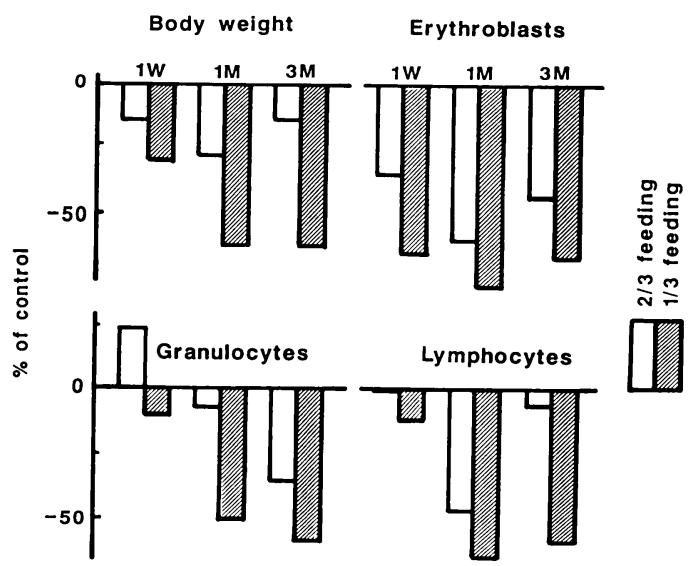

Fig. 4. Effect of food restriction on bone marrow cells in rat

treatment, and decrease in all kinds of marrow cells by $5-\mathrm{FU}$ treatment. Additionally, degrees of these changes by drug treatment were severer than those of four days starvation, demonstrating these effects are attributable to the drug toxicity.

This study not only made it possible to determine whether drugs have direct effects on the peripheral blood cells and/or bone marrow cells or not, but also underscore the usefulness of bone marrow examination in the safety study.

3) Effect of restricted feeding on bone marrow cells in rats

It is well known that when a chemical is added to the food or administered to animals in the subacute or chronic toxicity test, volume of food consumption in the heigher dose groups is occasionally reduced. In the previous papers $[3,4,14]$, food restriction resulted in prolonging the life span and in delaying the onset of major diseases, including neoplasms. Accordingly, as nutritional factors may influence the results of toxicology testing, paired feeding studies [33] restricting food intake to $66 \%$ or $33 \%$ of control for three months were carried out employing Slc: Wistar rats (Fig. 4).

In parallel to the depression of body weight gain, the number of erythroblasts was markedly reduced one week after the start of treatment whereas decreases in granulocytes and lymphocytes were observed one month after the treatment. Thus, restricted feeding resulted in a decrease in all bone marrow cells with reduction of the $\mathrm{G} / \mathrm{E}$ ratio.

The findings of the bone marrow examination represented here should be useful for evaluating drug safety based on the results of subchronic and/or chronic toxicity testings in which the test material is mixed in the diet and administered to rats.

\section{Bone marrow in immune-deficient animals and immunotoxicity testing}

1) Bone marrow cells in immune-deficient animals

Many immune-deficient animals are now proving to be invaluable model systems in biomedicine, and they have also become practical tools applied to various fields of biology and medicine. We selected the MRL/lpr mouse [1], a model of autoimmune disease due to an expansion of a unique $\mathrm{T}$-lymphocyte subset, to determine age-associated changes of bone marrow cells in this mouse strain (Table 3) [25].

It was found that granulocytosis, particularly the increase in the number of neutrophils, developed in these mice at 2 months of age when proliferating lpr cells appeared first in the lymph node and spleen, and progressed thereafter. Additionally, proliferation of plasma cells derived from B cells was also observed at 
Table 3. Age-associated changes in the number of bone marrow cells ( $\times 10^{4} /$ femur) in MRL/lpr mice

\begin{tabular}{lcccc}
\hline \multirow{1}{*}{ Differential } & \multicolumn{4}{c}{ Age (months old) } \\
\cline { 2 - 5 } & 1 & 2 & 4 & 6 \\
\hline Proerythroblasts & $10 \pm 3$ & $10 \pm 4$ & $12 \pm 5$ & $22 \pm 7$ \\
Basophilic erythroblasts & $35 \pm 6$ & $43 \pm 9$ & $39 \pm 7$ & $101 \pm 41$ \\
Polychromatic erythroblasts & $328 \pm 25$ & $326 \pm 57$ & $304 \pm 20$ & $469 \pm 118$ \\
$\quad$ Total erythroblasts & $373 \pm 23$ & $379 \pm 62$ & $355 \pm 27$ & $592 \pm 154$ \\
Myeloblasts & $8 \pm 4$ & $11 \pm 7$ & $15 \pm 3$ & $24 \pm 10$ \\
Promyelocytes, Neutrophilic & $17 \pm 2$ & $17 \pm 9$ & $33 \pm 11$ & $48 \pm 19$ \\
Myelocytes, Neutrophilic & $35 \pm 4$ & $68 \pm 16$ & $71 \pm 20$ & $137 \pm 29$ \\
Metamyelocytes, Neutrophilic & $55 \pm 11$ & $113 \pm 27$ & $141 \pm 23$ & $257 \pm 84$ \\
Mature Neutrophils & $241 \pm 24$ & $424 \pm 34$ & $606 \pm 23$ & $880 \pm 118$ \\
Eosinophils & $33 \pm 13$ & $28 \pm 7$ & $32 \pm 5$ & $55 \pm 26$ \\
$\quad$ Total granulocytes & $389 \pm 55$ & $661 \pm 59$ & $898 \pm 60$ & $1401 \pm 168$ \\
G/E ratio & 1.04 & 1.74 & 2.53 & 2.37 \\
Lymphocytes & $199 \pm 28$ & $141 \pm 43$ & $185 \pm 66$ & $257 \pm 70$ \\
Plasma cells & 0 & 0 & $3 \pm 3$ & $31 \pm 14$ \\
Monocytes & $12 \pm 6$ & $20 \pm 6$ & $27 \pm 9$ & $67 \pm 34$ \\
Macrophages & $2 \pm 3$ & $4 \pm 2$ & $3 \pm 2$ & $2 \pm 3$ \\
Reticulum cells & $1 \pm 1$ & $2 \pm 1$ & $2 \pm 1$ & $2 \pm 2$ \\
Megakaryocytes & $1 \pm 2$ & $1 \pm 2$ & $3 \pm 3$ & $5 \pm 5$ \\
Mitotic cells & $10 \pm 2$ & $10 \pm 6$ & $12 \pm 6$ & $17 \pm 10$ \\
Other cells & $3 \pm 2$ & $12 \pm 6$ & $14 \pm 7$ & $31 \pm 12$ \\
\hline
\end{tabular}

Each value represents mean $\pm \mathrm{SD}$ of 7 animals.

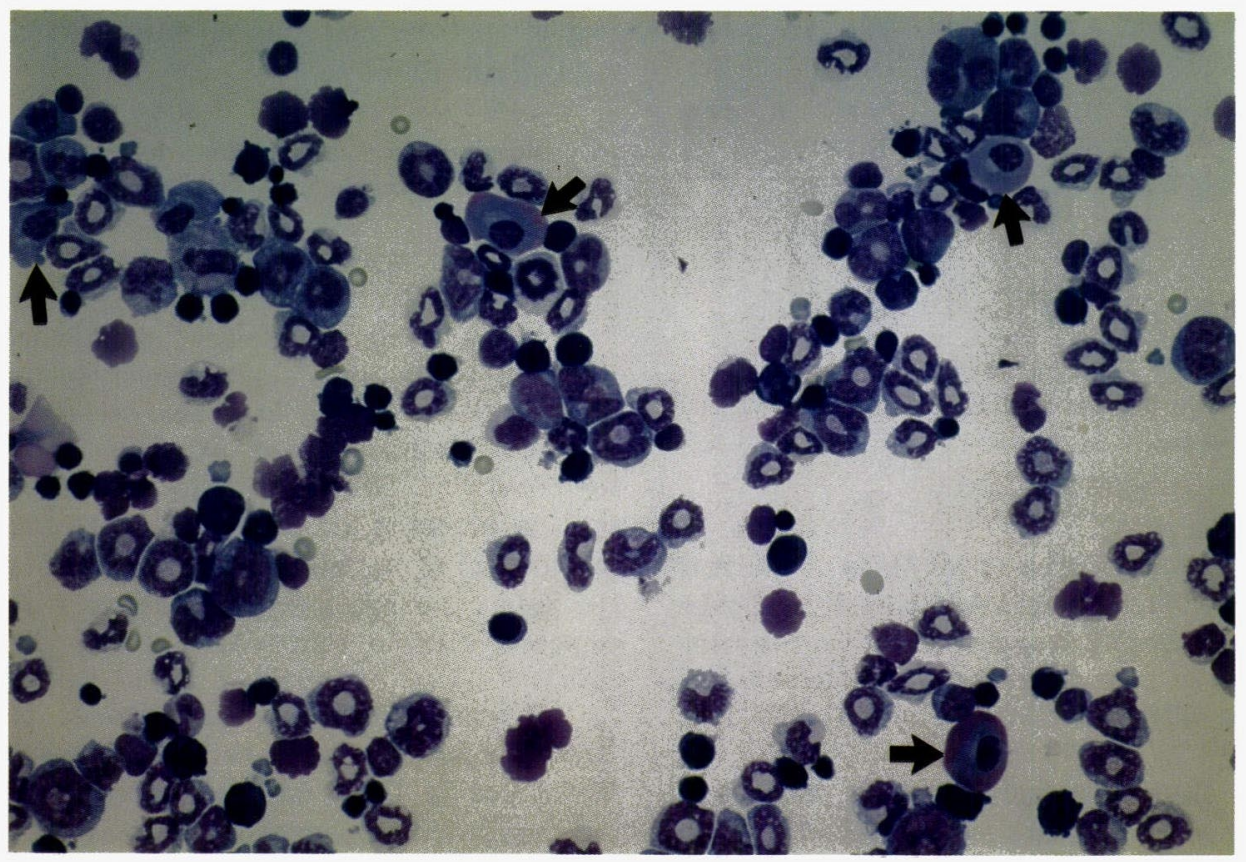

Photo. 1. Femoral bone marrow of MRL/lpr mouse ( 6 months old) showing granulocytosis and proliferation of plasma cells (arrows) Wright-Giemsa staining 
6 months of age (Photo. 1). Thus, the bone marrow examination in this mouse strain made it possible to find that abnormalities of proliferation of both neutrophils and plasma cells play important roles in immunological function, in addition to the proliferation of abnormal $\mathrm{T}$ cells as previously reported $[19$, 30].

Another study [39] of bone marrow examination in KSN mice, a strain of self-perpetuating nude mice, also revealed interesting result of higher granulocyte count in the bone marrow compared to BALB/c nude mice.

2) Bone marrow examination in immunotoxicity testing

New biotechnology products are now being approved and include a variety of products such as interferons, cytokines, hormones and other regulatory factors. A target organ of these chemicals is thought to be immune system. In fact, interferons and cytokines affect blood and bone marrow cells [38, 41, 42, 45].

Recentry, it has been argued that because of complexity of the immune system and the varied nature of the many possible consequences of immunotoxicity, histopathology and other data generated in conventional toxicity testing may not be a sufficient indication of toxic effects and that immunological testing may be required $[6,8]$. Although documenting toxic effects on the immune system is a difficult task, it is desirable to establish a set of immunologic tests that could be applied to the study of the toxicological properties of a wide range of suspected substances.

With this as a background for the purpose of developing practical methods of assessing the immunotoxic potential of chemicals, the effects of 28 days of oral treatment with azathioprine on lymphoid system of rats and its general toxic actions were studied [26]. Remarkable findings in this study were that significant reductions in thymus weight and in the numbers of lymphocytes and granulocytes in both peripheral blood and bone marrow were observed but functional test data did not show the same effects.

Formerly, bone marrow examination is employed in diagnosis of an anemic process or for verification of suspected leukemia when peripheral blood findings are not clearly diagnostic. Although, from only one test result, it is too early to determine which of these test items will be most valuable, it seems likely that bone marrow examination will be one useful parameter for evaluating immunotoxicity induced by chemicals. It also is necessary that other functional test systems and techniques be developed in rat.

This bone marrow assay procedure has seen only limited use for the evaluation of drug induced myelotoxicity, but is now being used with greater frequency to determine the toxic potential of chemicals on bone marrow cells.

\section{N . Further problems}

It is well agreed that the stem cell is a progenitor cell and capable of supplying each hematopoietic cell series. Although morphological identification of this cell is not possible at the present time $[10,31]$, reports $[20,43]$ that multi-potential stem cells, as measured by the CFU (colony forming unit), is responsive to the effect of known myelotoxic agents are available. Thus, in terms of myelotoxicity testing in the safety study, it seems likely that a combination of morphological bone marrow examination and this CFU assay or other methods like flow cytometry analysis [15, 17] should be used in order to contribute to the reliable toxicological investigation.

On the other hand, there is the known inter-observer variability for interpretation of morphological findings in maturation stage such as bands, metamyelocyetes, blast cells etc.. In order to reduce this inter-observer variability, it will be necessary to develop a tentative reference differential counting method including the preparation procedure for smearing the bone marrow cellls of experimental animals.

In any case, the topic of bone marrow examination continues to hold much interest in the safety study.

In conclusion, the major emphasis of this paper has been to point out the importance of bone marrow examination for evaluating the safety of chemicals.

The evidence presented here is that (1) the highest and the lowest values of $\mathrm{G} / \mathrm{E}$ ratio throughout the life are seen within 4 days after birth in rat ; (2) four days administration of drug, if it has myelotoxicity, can be expected to produce fluctuation of bone marrow cellu- 
larity ; (3) feed restriction results in a reduction of bone marrow cell count with elevation of $\mathrm{G} / \mathrm{E}$ ratio ; (4) bone marrow examination of autoimmune-prone MRL/lpr mice reveals abnormal proliferation of granulocytes and plasma cells which has not been reported ; and (5) bone marrow examination plays an important role in immunotoxicity testing.

\section{References}

[1] Andrews, S. R., Eisenberg, A. N., Theofilopoulos, S., Izui, C. B., Wilson, P. J., McConahey, E. D., Murphy, D. E., Roths, J. B., and Dixon, F. J. (1978). Sponaneous murine-lupus like syndromes. Clinical and immunopathological manifestations in several strains. J. Exp. Med, 148, 1198-1215.

[2] Barrett, D. L. and King, E. B. (1976). Comparison of cellular recovery rates and morphologic detail obtained using membrane filter and cytocentrifuge techniques. Acta. Cytol, 20, 174-180.

[3] Berg, B. N. (1960). Nutrition and longevity in the rat, I. Food intake in relation to size, health and fertility. J. Nutrition 71, 242-254.

[4] Berg, B. N. (1960). Nutrition and longevity in the rat, II. Longevity and onset of disease with different levels of food intake. J. Nutrition, 71, 255-263.

[5] Caird, F. I., Andrews, G. R., and Gallie, T. B. (1971). The leukocyte count in old age. Age Aging, 1, 239248.

[6] Commission of the EC (1989). Guidelines on the preclinical biological safety testing of medical products derived from biotechnology. TIBTECH 7, G 13- G 16.

[7] Constable, T. A. and Blackett, N. M. (1972). Comparison of effect of four cytotoxic agents on granulocytic and erythroid repopulating ability of rat bone marrow. J. Natl Cancer Inst., 148, 941-948.

[8] Dayan, A. D. (1987). Rationality and regulatory requirements : A View from Britain. In Preclinical Safety of Biotechnology Products Intended for Human Use. pp. 89-106, Graham, C. E. (edit), Alan R. Liss, Inc., New York.

[9] Diaz-Jouanen, E., Strickland, R. G., and Williams, R. C. (1975). Studies of human lymphocytes in the newborn and the aged. Am J. Med, 58, 620-633.

[10] Dicke, K. A., van Noord, B. J., Maat, B., Schaffer, U. W., and van Bekkum, D. W. (1973). Attempts at morphological identification of the haemopoietic stem cell in primates and rodents. In Ciba Found Symposium 13 (New series), Haemopoietic stem cell. pp. 47-69. Elsevier Excerpta Medica, Amsterdam.

[11] Dore, C. F. and Balfour, B. M. (1965). A device for preparing cell spreads. Immunology, 9, 403-405.

[12] Fairman, E. and Whipple, G. H. (1933). Bone marrow volume in adult dogs. Amer. J. Phisiol, $104352-$ 359.

[13] Fujimoto, S. and Ogawa, M. (1980). Lethal toxicity and myelotoxicity to mice of the combination of 6 thioguanine and $3-[(4-$ amino-2-methyl-5-pyrimidinyl) methyl]-1-(2-chiloroethyl)-1-nitrosourea hy- drochloride. Gann 71, 667-673.

[14] Hayashi, Y., Takahashi, M., and Kokubo, T. (1984). Nutritional factors influencing the results of toxicology experiments in animals. J. Toxicol Sci, 9, 219-234.

[15] Horan, P. K. and Wheelles, L. L. (1977). Quantitative single cell analyses and sorting. Science, 198, 149-154.

[16] Hudson, G. (1965). Bone marrow volume in the human foetus and newborn. Brit. J. Haematol, 11, 446-455.

[17] Irons, R. D. (1981). Benzene-induced myelotoxicity : Application of flow cytofluorometry for the evaluation of early proliferative change in bone marrow. Environ Health Perspect., 39, 39-49.

[18] Lee, E. W., Kocsis, J. J., and Snyder, R. (1981). The use of ferrokinetics in the study of experimental anemia. Environ Health Perspect., 39, 29-37.

[19] Lewis, D. E., Giorgi, J. V., and Warner, N. L. (1981). Flow cytometry analysis of $T$ cells and continuous T-cell lines from autoimmune MRL/l mice. Nature, 289, 298-300.

[20] Mangalik, A. and Robinson, W. A. (1981). Stem cell assays in the evaluation of myelotoxicity. Environ. Health Perspect., 39, 51-58.

[21] Matsumoto, K. (1984). Changes of bone marrow cell and peripheral blood cell counts in new-born mice. Exp. Anim, 33, 339-44.

[22] Matsumoto, K., Furuya, T., and Tobe, M. (1984). Effect of mitomycin $\mathrm{C}$ on bone marrow cells in mice. J. Toxicol Sci, 9, 51-56.

[23] Matsumoto, K., Ochiai, T., Hagino, K., Sekita, K., Kawasaki, Y., and Furuya, T. (1981). Differential bone marrow cell counts of new born rats : Changes of cellular composition during zero to six days of age. J. Tokyo Vet. Zootechn Sci, 29, 137-141.

[24] Matsumoto, K., Ochiai, T., Sekita, K., Kawasaki, Y., Yasuhara, K., Nakaji, Y., Furuya, T., Kurokawa, Y., and Tobe, M. (1987). Six-month toxicity study of mitomycin C in marmoset. J. Toxicol Sci, 12, 583.

[25] Matsumoto, K., Sakamoto, Y., and Hirose, S. (1989). Granulocytosis and its correlation to lymphoproliferative disorder in autoimmune-prone $\mathrm{MRL} / \mathrm{lpr}$ mice. Juntendo Med J., 35, 106-116. (in Japanese)

[26] Matsumoto, K., Sekita, K., Ochiai, T., Takagi, A., Furuya, T., Kurokawa, Y., Teshima, R., Suzuki, K., Sawada, J., and Terao, T. (1990). Evaluation of immunotoxicity testings using azathioprine-treated rats: The international collaborative immunotoxicity study. Bull Natl Inst. Hygi Sci, 108, in press. (in Japanese)

[27] Matsumoto, K. and Shirai, T. (1987). Basic study on drug induced myelotoxicity: An application of bone marrow testing to toxicity study. Juntendo Med J., 33, 74-86. (in Japanese)

[28] Matsumoto, K., Usui, A., Ochiai, T., Sekita, K., Kawasaki, Y., Naito, K., Nakaji, Y., Furuya, T., and Tobe, M. (1986). Short-term toxicity study of 4dimethylaminoazobenzen in marmosets. J. Toxicol Sci, 11, 335-343.

[29] Ministry of Health and Welfare (1984). Information on the guidelines of toxicity studies required for applications for approval to manufacture (import) drugs. Notification No. 188 of the Pharmaceutical 
Affaifs Bureau., Fed. 15.

[30] Morse, H. D., Davidson, W. F., Yetter, E. D., Murphy, J. B., and Coffman, R. L. (1982). Abnormalities induced by the mutant gene lpr : expression of a unique lymphocyte subset. J. Immunol, 129, 26122615.

[31] Nicola, N. A., Metcalf, D., von Melchner, H., and Burgess, A. W. (1981). Isolation of murine fetal hemopoietic progenitor cells and selective fractionation of various erythroid precursors. Bllod 58, 376-386.

[32] Nye, R. N. (1931). Bone marrow volume in rabbits. Pro. Soc. Exp. Biol Med, 29, 34-40.

[33] Ogawa, Y., Matsumoto, K., Kamata, E., Ikeda, Y., and Kaneko, T. (1985). Effect of feed restriction on peripheral blood and bone marrow cell counts of Wistar rats. Exp. Anim, 34, 407-416.

[34] Philips., F. S., Schwarts, H. S., and Sternberg, S. S. (1960). Pharmacology of mitomycin C, I. Toxicity and pathologic effects. Cancer Res., 1354-1361.

[35] Pharmaceutical Manufacturers Association (1989). 1989 Annual survey from patent to products, U. S. strong in genetically engineered medicines. In Development Biotechnology Medicine, PMA, USA.

[36] Ramsell, T. G. and Yoffey, J. M. (1961). The bone marrow of the adult rat. Acta Anat., 47, 55-65.

[37] Society of Agricultural Chemical Industry (1985). Testing guidelines for toxicology studies. In Guidance of Toxicology Study Data for Application of Agricultural Chemical Registration, pp. 31-44, Society of Agricultural Chemical Industry, Tokyo.

[38] Souza, L. M., Boone, T. C., Gabrilove, J., Lai, P. H., Zsebo, K. M., Murdock, D. C., Chazin, V. R., Bruszewski, J., Lu, H. Chen, K. K., Barendt, J., Platzer, E., Moore, M. A., Mertelsmann, R., and Welte, K. (1986). Recombinant human granulocyte colonystimulating factor: Effects on normal and leukemic myeloid cells. Science, 232, 61-65.

[39] Sudo, K., Suzuki, K., Matsumoto, K., Furuya, T., and Kurokawa, Y. (1989). Characteristics of KSN inbred mice : A strain of self-perpetuating nude mice. In Immune-deficient Animals in Experimental Medicine, pp. 45-49, Wu, B. and Zheng, J. (edit), Karger, Basel.

[40] Tarbutt, R. G. and Blackett, N. M.(1974). Acceleration of granulopoietic recovery by androgenic steroids in mice made neutropenic by cytotoxic drugs. Cancer Res., 34, 2517-2520.

[41] Ulich, T. R., Castillo, J., Keys, M., Granger, G. A., and $\mathrm{Ni}, \mathrm{R}$. (1987). Kinetics and mechanisms of recombinant human interleukin 1 and tumor necrosis factor-alpha-induced changes in circulating numbers of neutrophils and lymphocytes. J. Immunol, 139, 3406-3415.

[42] Ulich, T. R., Castillo, J., Keys, M., and Granger, G. A. (1987). Recombinant human alpha lymphotoxin (tumor necrosis factor-beta) induces peripheral neutrophilia and lymphopenia in the rat. Am J. Pathol, 128, 5-14.

[43] Vardian, J. W. and Variakojis, D. (1982). The hematopoietic system. In Pathology of Drug-induced and Toxic Diseases. pp. 87-118, Riddell, R. H. (edit), Churchill Livingstone, N. Y.

[44] Weihe, W. H. (1987). The laboratory rat. In The UFAW Handbook on the Care and Management of Laboratory Animals, pp. 309-330, Poole, T. B. (edit), Longman Sci. Tech., U. K..

[45] Yang, Y., Ciarletta, A. B., Temple, P. A., Chung, M. P., Kovacic, S., Witek-Giannotti, J. S., Leary, A. C., Kriz, R., Donahue, R. E., Wong, G. G., and Clark, S. C. (1986). Human IL-3 (multi-CSF) : Identification by expression cloning of a novel hematopoietic growth factor related to murine IL -3. Cell, 47, 310 .

\title{
実験動物の骨髄細胞に関する研究： 安全性試験に打ける骨髄検査
}

\author{
松本清司
}

\section{信州大学医学部附属動物実験施設}

実験動物を用いて行われる安全性試験は，人類の健康 保持や豊かな社会生活を維持するために重要である。こ の試験に，骨髄細胞数と細胞分別の測定からなる骨髄検 査を応用する目的で，実験動物の骨髄細胞に関する基 礎的検討を行い，次のような結果を得た。1）各種実験 動物の骨䯣細胞数を調べたところ，大型の動物ほど細胞 密度が低い傾向を示した。2）骨䯣細胞分別を目的と する塗抹標本の作成にはサイトスピン法が適していた。 3) 安全性試験で多用されるラットの骨髄紏胞構成比を 生涯にわたり調べたところ，各骨髄細胞数が安定するの
は9 週龄頃であり, 雄ラットの性成熟の時期と一致し た。4）種々の化学物質の骨䯣に及ぼす影響を調べたと ころ, 大量投与では 4 日以内に物質の直接または間接影 響による各骨䯣細胞の增殖あるいは抑制像が認められ た。 5）ラットで 3 カ月間の制限給慨を行らと， G/E 比の上昇を伴う骨㖪細胞数の減少が見られた。6）自己 免疫疾患モデル動物である MRL/lpr マウスで骨䯣検 查を実施したところ，今までに報告されていない骨䯣顆粒 球と形質細胞の增殖が認められた。7）近年開発されは じめたバイオ医薬品に関連し, 免疫毒性検索法を検討す 
るために，免疫抑制剤投与ラットで骨髄検査を実施した ところ, 毒性評価上有用な結果が得られた。以上, 安全 性試験を中心に著者らが行った実験動物の骨䯣細胞の形
態学的検索に関する一連の成績を示し, 安全性試験にお ける骨髄検査の重要性と問題点について述べた。 